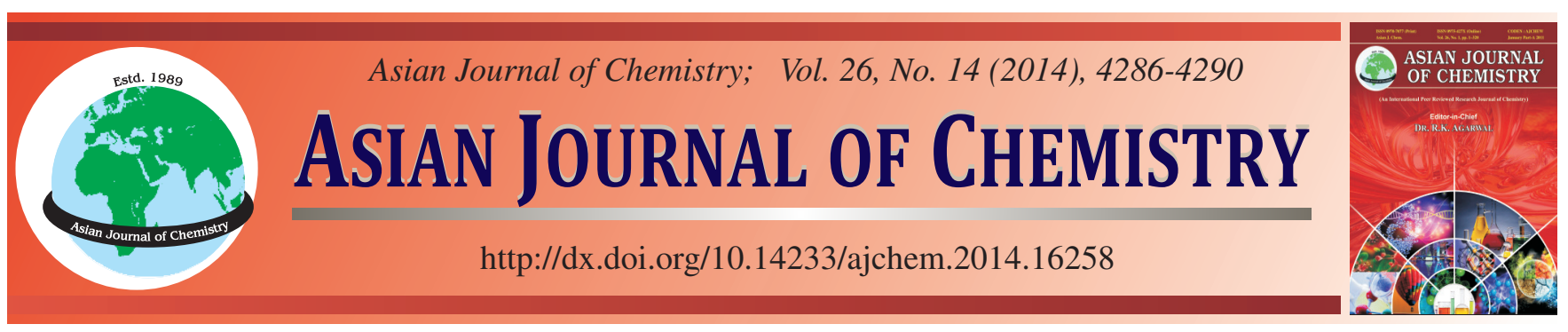

\title{
Isolation, Docking and Cytotoxicity Evaluation Against Cholangiocarcinoma of Labdanes from Curcuma petiolata
}

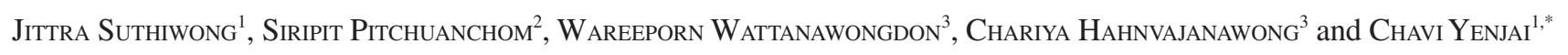

${ }^{1}$ Natural Products Research Unit, Center of Excellence for Innovation in Chemistry, Department of Chemistry, Faculty of Science, Khon Kaen University, Khon Kaen, 40002, Thailand

${ }^{2}$ Laboratory of Natural Products, Faculty of Science and Center of Excellence for Innovation in Chemistry, Lampang Rajabhat University, Lampang, 52100, Thailand

${ }^{3}$ Department of Microbiology, Liver Fluke and Cholangiocarcinoma Research Center, Faculty of Medicine, Khon Kaen University, Khon Kaen 40002, Thailand

*Corresponding author: E-mail: chayen@kku.ac.th

Labdanes 1-4, stigmasterol (5) and vanillin (6) were isolated from the rhizomes of Curcuma petiolata. Compounds 2-4 exhibited strong to moderate cytotoxicity against cholangiocarcinoma cell lines. Compound $\mathbf{3}$ showed strong cytotoxicity with $\mathrm{IC}_{50}$ values ranging from $5-11 \mu \mathrm{g} / \mathrm{mL}$. The molecular modeling was studied using the AutoDock 4 program. The docking results reveal that 3 interacted with EGFR through the $2 \mathrm{H}$-bond at Gln767 and Met769 with binding energy of $-6.89 \mathrm{kcal} / \mathrm{mol}$.

Keywords: Curcuma petiolata, Labdane, Cholangiocarcinoma, Epidermal growth factor receptor.

\section{INTRODUCTION}

Cholangiocarcinoma is a major public health problem in Thailand, especially in the northeast region ${ }^{1}$. It is difficult to diagnose this disease at an early stage, so the only way to cure the disease is resection. However, more than half of this cancer patients have not been resected due to the late stage of finding the cancer. It has been reported that chemotherapy and radiotherapy for this tumor are not effective ${ }^{2}$. The infection from liver fluke, Opisthorchis viverrini, causes cholangiocarcinoma which has been proven both in human and experimental animals ${ }^{3}$. In Thailand, it has been found that this cancer occurs in men more than women due to the high prevalence of liver fluke infections.

We have previously reported the cytotoxicity against cholangiocarcinoma of chemical constituents and modified compounds from natural sources and also a computational study ${ }^{4-6}$. In the present work, we investigated the cytotoxicity against cholangiocarcinoma cell lines of four labdane diterpenes from Curcuma petiolata. In addition, the interaction between the isolated compounds and the epidermal growth factor receptor (EGFR), the significant prognostic receptor proteins $^{7,8}$, was studied using molecular modeling techniques.

Curcuma petiolata, belongs to the Zingiberaceae family, is widespread in the North and Northeast of Thailand and cultivated in Kaeng Khro district, Chaiyaphum province, Thailand. The rhizomes of C. petiolata are used as a febrifuge, tonic, excitant, anti-inflammatory and for anticancer activities. C. longa, one of the plants in the Curcuma genus, is widespread in South East Asian countries'. In Thailand, C. longa is usually used as a food colouring agent. Moreover in Thai folk medicine, it has been used as a fever alleviator and it has potential for cancer prevention. The major chemical constituents in this plant are curcuminoids, sesquiterpene and labdane type diterpenes $^{10,11}$. It has been found that labdanes exhibit cytotoxicity against several cell lines such as S102 (hepatocellular carcinoma), A549 (lung adenocarcinoma), MOLT-3 (T-lymphoblast), KB (epidermoid carcinoma), HeLA (cervical carcinoma), T-47D (hormone-dependent breast cancer) and HL-60 (human promyelocytic leukemia cell) ${ }^{11,12}$. We expected that labdanes from C. petiolata would exhibit interesting results against cholangiocarcinoma cell lines.

\section{EXPERIMENTAL}

Melting points were determined on a SANYO Gallenkamp (UK) melting point apparatus and are uncorrected. IR spectra were recorded as $\mathrm{KBr}$ disks or thin films, using Perkin Elmer Spectrum One FT-IR spectrophotometer (UK). The NMR spectra were recorded on a Varian Mercury plus spectrometer (UK) operating at $400 \mathrm{MHz}\left({ }^{1} \mathrm{H}\right)$ and at $100 \mathrm{MHz}\left({ }^{13} \mathrm{C}\right)$. Mass 
spectra were determined on Micromass Q-TOF 2 hybrid quadrupole time-of-flight (Q-TOF) mass spectrometer with a Z-spray ES source (Micromass, Manchester, UK). Thin layer chromatography (TLC) was carried out on MERCK silica gel $60 \mathrm{~F}_{254}$ TLC aluminum sheet. Column chromatography was done with silica gel $0.063-0.200 \mathrm{~mm}$ or less than $0.063 \mathrm{~mm}$. Preparative layer chromatography (PLC) was carried out on glass supported silica gel plates using silica gel 60 PF254 for preparative layer chromatography. All solvents were routinely distilled prior to use.

The rhizomes of $C$. petiolata were collected in September 2012 from Kaeng Khro district, Chaiyaphum province. A botanically identified voucher specimen (KKU0022012) was deposited at the herbarium of the Department of Chemistry, Faculty of Science, Khon Kaen University, Thailand.

Extraction and isolation: Air dried rhizomes of C. petiolata were ground into powder and then extracted successively with EtOAc $(2 \mathrm{~L} \times 3)$ and $\mathrm{MeOH}(2 \mathrm{~L} \times 3)$ at room temperature. The filtrates were combined and the solvents were evaporated in vacuo to yield crude EtOAc (33 g) and $\mathrm{MeOH}(21 \mathrm{~g})$, respectively. The crude EtOAc extract ( $33 \mathrm{~g}$ ) was subjected to flash column chromatography (FCC) and eluted with a gradient system of hexane:EtOAc and EtOAc:MeOH. The fractions which contained the same major compounds were combined to give four fractions, F1-F4. Fraction F1 was subjected to flash column chromatography and eluted with a gradient of hexane: EtOAc to give three subfractions, F1.1-F1.3. Subfraction F1.2 was rechromatograph on reverse phase (RP-18) FCC and eluted with an isocratic system of $\mathrm{MeOH}: \mathrm{H}_{2} \mathrm{O}$ (70:30) to give two subfractions, F1.2.1 and 1.2.2. F1.2.1 was purified by PLC using hexane:EtOAc (80:20) as developing solvent to afford 1 (43.4 mg). Subfraction F1.2.2 was purified by PLC using $\mathrm{CH}_{2} \mathrm{Cl}_{2}$ as developing solvent to give 5 (150 mg) and 6 (10.4 $\mathrm{mg}$ ). Fraction F2 was subject to flash column chromatography and eluted with a gradient system of hexane: $\mathrm{CH}_{2} \mathrm{Cl}_{2}$ to give two subfractions, F2.1 and F2.2. Both F2.1 and F2.2 were purified by PLC using $\mathrm{CH}_{2} \mathrm{Cl}_{2}$ as developing solvent to afford $\mathbf{2}(10.3 \mathrm{mg})$ and $\mathbf{3}(14.3 \mathrm{mg})$, respectively. Further purification of fraction $\mathrm{F} 3$ by PLC using $\mathrm{CH}_{2} \mathrm{Cl}_{2}$ as developing solvent afforded 4 (11.2 $\mathrm{mg})$.

(E) Labda-8(17),12-diene-15,16-dial (1): It was obtained as colourless oil, $43.4 \mathrm{mg}(0.0039 \%) . \mathrm{R}_{f}=0.42(20 \%$ EtOAc:hexane); $\left([\alpha]^{20}{ }_{\mathrm{D}}+14.17^{\circ}\right)(4.8 \mathrm{mg} / 2 \mathrm{~mL})$; IR (thin film, $\left.v_{\max }, \mathrm{cm}^{-1}\right)$ : 3080, 2931, 2845, 2718, 1725, 1681, 1641, 1457, $1385,1263,1166,1088,1027,890,755 ;{ }^{1} \mathrm{H}\left(400 \mathrm{MHz}, \mathrm{CDCl}_{3}\right)$ $\delta 0.72(3 \mathrm{H}, \mathrm{s}, \mathrm{H}-20) 0.81$ (3H, s, H-19), 0.88 (3H, s, H-18), $1.07, \mathrm{~m}, \mathrm{H}-1 \mathrm{a}), 1.13$ (1H, dd, $J=12.6,2.3, \mathrm{H}-5), 1.20(1 \mathrm{H}$, $\mathrm{dd}, J=13.3,4.2, \mathrm{H}-3 \mathrm{a}), 1.34$ (1H, dd, $J=12.9,4.2, \mathrm{H}-3 \mathrm{~b})$, 1.35 (1H, m, H-6a), 1.40, m, H-2a), 1.57 (1H, m, H-2b), 1.68 $(\mathrm{d}, J=12.4, \mathrm{H}-1 \mathrm{~b}), 1.75$ (1H, m, H-6b), 1.89 (1H, d, $J=11.2$, H-9), 2.02 (1H, m, H-7a), 2.36-2.27 (1H, m, H-11a), 2.40 (1H, m, H-7b), 2.51-2.44 (1H, m, H-11b), 3.38 (1H, d, J = 16.8, H$14 \mathrm{a}), 3.45$ (1H, d, $J=16.8, \mathrm{H}-14 \mathrm{~b}), 4.35$ (1H, br s, H-17a), $4.85(1 \mathrm{H}$, br s, H-17b), $6.75(1 \mathrm{H}, \mathrm{t}, J=6.4, \mathrm{H}-12), 9.39(1 \mathrm{H}, \mathrm{s}$, $\mathrm{H}-16), 9.62(1 \mathrm{H}, \mathrm{s}, \mathrm{H}-15) ;{ }^{13} \mathrm{C}\left(100 \mathrm{MHz}, \mathrm{CDCl}_{3}\right) \delta 14.4$ (C-20), 19.2 (C-2), 21.7 (C-19), 24.1 (C-6), 24.6 (C-11), 33.5 (C-4), 33.5 (C-18), 37.8 (C-7), 39.2 (C-1), 39.3 (C-14), 39.6 (C-10), 41.9 (C-3), 55.4 (C-5), 56.4 (C-9), 107.8 (C-17), 134.8 (C-13), 148.1 (C-8), 159.9 (C-12), 193.5 (C-16), 197.3
(C-15). HRESIMS $\mathrm{m} / \mathrm{z} 325.2100[\mathrm{M}+\mathrm{Na}]^{+}$(calcd for $\left.\mathrm{C}_{20} \mathrm{H}_{30} \mathrm{O}_{2} \mathrm{Na}, 325.2136\right)$.

15,16-Bisnorlabdan-8(17),11-dien-13-one (2): It was obtained as colourless oil, $10.1 \mathrm{mg}(0.0009 \%) . \mathrm{R}_{f}=0.45$ $\left(100 \% \mathrm{CH}_{2} \mathrm{Cl}_{2}\right) ;\left([\alpha]^{20}{ }_{\mathrm{D}}+1.43^{\circ}\right)(1.4 \mathrm{mg} / 2 \mathrm{~mL})\left(\right.$ lit. $[\alpha]^{25}{ }_{\mathrm{D}}+$ $\left.4.5^{\circ}, \mathrm{CHCl}_{3}, \mathrm{c} 0.3\right)$ [43]; IR (thin film) (KBr, $\left.v_{\max }, \mathrm{cm}^{-1}\right)$ : 2972, 2849, 1674, 1629, 1460, 1362, 1257, 1175, 1120, 992, 960, 892, 755; ${ }^{1} \mathrm{H}\left(400 \mathrm{MHz}, \mathrm{CDCl}_{3}\right) \delta 0.84(3 \mathrm{H}, \mathrm{s}, \mathrm{H}-20), 0.88$ (3H, s, H-18), 0.88 (3H, s, H-19), 1.08 (1H, m, H-1a), 1.09 (1H, dd, $J=12.6,2.4$, H-5), 1.21 (1H, dd, $J=13.3,4.2, \mathrm{H}-3 \mathrm{a})$, 1.33 (1H, br d, $J=12.9, \mathrm{H}-3 \mathrm{~b}), 1.35$ (1H, m, H-6a), $1.41(1 \mathrm{H}$, m, H-2a), 1.56 (1H, m, H-2b), 1.66 (1H, m, H-1b), 1.75 (1H, m, H-6b), 2.02 (1H, m, H-7a), 2.27 (1H, s, H-14), 2.40 (1H, m, H-7b), 2.45 (1H, br t, $J=10.3, \mathrm{H}-9), 4.40$ (1H, br s, H17a), 4.78 (1H, br s, H-17b), 6.06 (1H, d, $J=15.8, \mathrm{H}-12)$, $6.86(1 \mathrm{H}, \mathrm{dd}, J=15.8,10.3, \mathrm{H}-11) ;{ }^{13} \mathrm{C}\left(100 \mathrm{MHz}, \mathrm{CDCl}_{3}\right) \delta$ 15.1 (C-20), 19.0 (C-2), 21.9 (C-19), 23.2 (C-6), 27.2 (C-14), 33.5 (C-4), 33.5 (C-18), 36.6 (C-1), 39.3 (C-10), 40.8 (C-7), 42.1 (C-3), 54.4 (C-5), 60.8 (C-9), 108.6 (C-17), 133.6 (C-12), 146.6 (C-11), 148.6 (C-8), 198.1 (C-13). HRESIMS $\mathrm{m} / z$ 283.2001 $[\mathrm{M}+\mathrm{Na}]^{+}$(calcd for $\mathrm{C}_{18} \mathrm{H}_{28} \mathrm{ONa}, 283.2030$ ).

15-Epi-coronarin D (3): It was obtained as colourless oil, $14.3 \mathrm{mg}(0.0013 \%) . \mathrm{R}_{f}=0.32\left(100 \% \mathrm{CH}_{2} \mathrm{CL}_{2}\right) ;\left([\alpha]^{20}{ }_{\mathrm{D}}+\right.$ $\left.7.69^{\circ}\right)(3.9 \mathrm{mg} / 2 \mathrm{~mL})\left(\right.$ lit. $\left.[\alpha]_{\mathrm{D}}^{25}+16.4^{\circ}, \mathrm{CHCl}_{3}, \mathrm{c} 0.56\right)[46]$; IR (thin film, $v_{\max }, \mathrm{cm}^{-1}$ ): 3376, 2930, 2848, 2718, 1737, 1677, 1643, 1454, 1364, 1302, 1223, 1080, 1107, 1003, 944, 890, 756; ${ }^{1} \mathrm{H}\left(400 \mathrm{MHz}, \mathrm{CDCl}_{3}\right) \delta 0.69(3 \mathrm{H}, \mathrm{s}, \mathrm{H}-20), 0.79(3 \mathrm{H}, \mathrm{s}$, H-19), 0.86 (3H, s, H-18), 1.05 (1H, m, H-1a), 1.11 (1H, br d, $J=12.7, \mathrm{H}-5), 1.19$ (1H, m, H-3a), 1.31 (1H, m, H-6b), 1.39 $(1 \mathrm{H}, \mathrm{br} \mathrm{d}, J=13.2, \mathrm{H}-3 \mathrm{~b}), 1.50(1 \mathrm{H}, \mathrm{m}, \mathrm{H}-2 \mathrm{a}), 1.56(1 \mathrm{H}, \mathrm{m}$, H-2b), 1.69 (1H, m, H-1b), 1.70 (1H, m, H-6a), 1.85 (1H, m, H-9), 1.98 (1H, m, H-7a), 2.36 (1H, m, H-7b), 2.18 (1H, m, H-11a), 2.35 (1H, m, H-11b), 2.69 (1H, br d, $J=17.1, \mathrm{H}-$ 14a), 6.71 (1H, m, H-12), 3.01 (1H, m, H-14b), 4.80 (1H, br s, H-17a), 4.38/4.33 (1H, br s, H-17b isomer A and B), 5.93 $(1 \mathrm{H}, \mathrm{m}, \mathrm{H}-15) ;{ }^{13} \mathrm{C}\left(100 \mathrm{MHz}, \mathrm{CDCl}_{3}\right) \delta 14.3(\mathrm{C}-20), 19.3$ (C-2), 21.7 (C-19), 24.1 (C-6), 25.5 (C-11), 33.5 (C-4), 33.5 (C-18), 33.6/33.7 (C-14 isomers A and B), 37.7 (C-7), 39.2 (C-1), 39.4 (C-10), 42.0 (C-3), 55.3 (C-5), 56.1 (C-9), 96.4 (C-15), 107.6/107.3 (C-17 isomers A and B), 124.4/124.5 (C-13 isomers A and B), 143.5/143.6 (C-12 isomers A and B), 147.9/148.1 (C-8 isomers A and B), 170.6 (C-16). HRESIMS $m / z 319.2289[\mathrm{M}+\mathrm{H}]^{+}$(calcd for $\mathrm{C}_{20} \mathrm{H}_{31} \mathrm{O}_{3}, 319.2274$ ).

Coronarin D methyl ether (4): It was obtained as colourless oil, $10.4 \mathrm{mg}(0.0009 \%) . \mathrm{R}_{f}=0.39\left(100 \% \mathrm{CH}_{2} \mathrm{Cl}_{2}\right)$; $\left([\alpha]^{20}{ }_{\mathrm{D}}+7.5^{\circ}\right)(2.4 \mathrm{mg} / 2 \mathrm{~mL})\left(\right.$ lit. $[\alpha]^{25}{ }_{\mathrm{D}}+35^{\circ}, \mathrm{CHCl}_{3}, \mathrm{c}$ 0.32)[46]; IR (thin film, $v_{\max }, \mathrm{cm}^{-1}$ ): 2926, 2848, 1761, 1677, $1642,1446,1383,1342,1215,1183,1118,1016,943,889$, 755; ${ }^{1} \mathrm{H}\left(400 \mathrm{MHz}, \mathrm{CDCl}_{3}\right) \delta 0.71(3 \mathrm{H}, \mathrm{s}, \mathrm{H}-20), 0.81(3 \mathrm{H}, \mathrm{s}$, H-19), 0.88 (3H, s, H-18), 1.05 (1H, m, H-1a), 1.11 (1H, m, H-5), 1.20 (1H, dd, $J=13.4,3.7, \mathrm{H}-3 \mathrm{a}), 1.32$ (1H, dd, $J=$ 13.0, 4.2, H-6a), 1.40 (1H, br d, $J=13.1, \mathrm{H}-3 \mathrm{~b}), 1.51(1 \mathrm{H}, \mathrm{m}$, H-2a), 1.57 (1H, m, H-2b), 1.68 (1H, m, H-1b), 1.74 (1H, m, H-6b), 1.85 (1H, m, H-9), 1.98 (1H, m, H-7a), 2.20 (1H, m, H-11a), 2.35 (1H, m, H-11b), 2.38 (1H, m, H-7b), 2.69 (1H, br d, $J=17.3, \mathrm{H}-14 \mathrm{a}), 2.99$ (1H, m, H-14b), 3.52/3.51 (3H, s, $\mathrm{OCH}_{3}$ isomers $\mathrm{A}$ and $\left.\mathrm{B}\right), 4.81 / 4.35(1 \mathrm{H}$, br s, $\mathrm{H}-17 \mathrm{~b}$, isomers $\mathrm{A}$ and $\mathrm{B}), 4.82 / 4.39$ (1H, br s, H-17a, isomers A and B), 5.46 $(1 \mathrm{H}, \mathrm{m}, \mathrm{H}-15), 6.74$ (1H, m, H-12); ${ }^{13} \mathrm{C}\left(100 \mathrm{MHz}, \mathrm{CDCl}_{3}\right) \delta$ 
14.3 (C-20), 19.3 (C-2), 21.7 (C-19), 24.05/24.07 (C-6 isomers A and B), 25.4 (C-11), 33.5 (C-4), 33.5 (C-18), 33.75/33.78 (C-14 isomers A and B), 37.8 (C-7), 39.2/39.3 (C-1 isomers A and B), 39.4 (C-10), 41.97/41.99 (C-3 isomers A and B), 55.31/ 55.36 (C-5 isomers A and B), $56.1(\mathrm{C}-9), 56.6\left(\mathrm{OCH}_{3}\right), 102.1$ (C-15), 107.3/107.6 (C-17 isomers A and B), 123.8/123.9 (C13 isomers $\mathrm{A}$ and $\mathrm{B}), 143.1 / 143.2$ (C-12 isomers $\mathrm{A}$ and $\mathrm{B})$, 147.8/148.1 (C-8 isomers A and B), 169.7 (C-16); HRESIMS $m / z 333.2410[\mathrm{M}+\mathrm{H}]^{+}$(calcd for $\mathrm{C}_{21} \mathrm{H}_{32} \mathrm{O}_{3} \mathrm{Na}, 333.2430$ ).

Cytotoxicity assay: Cytotoxic activity of the compounds was determined by the sulforhodamine B (SRB) assay ${ }^{13}$. Briefly, $190 \mathrm{~mL} /$ well of cell suspensions $\left(0.5-1.0 \times 10^{5}\right.$ cells/ $\mathrm{mL}$ ) were seeded in 96 -well plates and incubated at $37^{\circ} \mathrm{C}$ for $24 \mathrm{~h}$. Then $10 \mathrm{~mL} /$ well of each concentration of the compounds was added in triplicate to obtain final concentration of 0.025 , $0.16,0.8,4$ and $20 \mathrm{mg} /$ well and $0.1 \%$ DMSO was used as the solvent-control wells. The plates were incubated for $1 \mathrm{~h}$ (starting cells) and $72 \mathrm{~h}$ at $37^{\circ} \mathrm{C}$. At the end of each exposure time, the medium was removed. The cells were fixed with $20 \%$ (w/v) trichloroacetic acid (TCA, Sigma, St. Louis, MO, USA) at $4{ }^{\circ} \mathrm{C}$ for $1 \mathrm{~h}$ and stained with $0.4 \%$ (w/v) SRB (Sigma) dissolved in $1 \%$ acetic acid (Sigma) at room temperature for $0.5 \mathrm{~h}$. After five times washing with $1 \%$ acetic acid, proteinbound dye was solubilized with $10 \mathrm{mM}$ Tris base, $\mathrm{pH} 10$ (Sigma) and the absorbance (OD) at $510 \mathrm{~nm}$ was determined with an ELISA plate reader (ELX-800; Bio-Tek Instruments, Inc.). Percentage cell viability was calculated as: [(OD treated cells on day 3-OD starting cells)/(OD control on day 3-OD starting cells) $] \times 100$. Dose-response curves were plotted and growth inhibition of $50 \%\left(\mathrm{IC}_{50}\right)$ was determined as compound concentration which results in $50 \%$ reduction of total protein increase in control cells.

\section{Molecular modeling}

Template preparation: A crystallographic structure of epidermal growth factor receptor $(\mathrm{EGFR})^{8}$ bound to the selective inhibitor [6,7-bis(2-methoxy-ethoxy)quinazoline-4yl]-(3-ethynylphenyl)amine (ligand I) was selected as the docking template. This structure was obtained from the Protein Data Bank (http://www.rcsb.org/pdb/) (PDB codes: 1M17). In order to prepare the target protein as a template, ligand and crystallographic water were removed. Hydrogens and Gasteiger charges were assigned by using AutoDockTools $(\mathrm{ADT})^{14}$. Atomic salvation parameters, based on the Stouten model and fragmental volumes were added in accordance with the AutoDock force field ${ }^{15}$. A grid of $45 \times 45 \times 45 \AA$ and $0.375 \AA$ spacing was calculated around the docking area for all ligand atom types using AutoGrid 4.

Template validation: The crystal structure of native ligand I was used to redock with the EGFR template ${ }^{4}$. To prepare the inhibitors to dock to the constructed template, all hydrogens were added and Gasteiger charges were assigned for all inhibitors. Auto Dock Tools was used to merge nonpolar hydrogens and define which bonds were rotatable for each ligand. AutoDock 4 was employed to perform the docking calculation. Ligand I was docked to the developed EGFR templates by using a Lamarkian genetic algorithm search (LGA). The docking trial was initiated with a randomly generated population of 150 ligand orientations and the highest affinity configuration was selected after 2 million energy evaluations had been performed. Standard AutoDock parameters were used for the genetic algorithm: $2 \%$ point mutation; $80 \%$ cross over rate; $6 \%$ local search rate. The resulting ligand configurations, from 150 trials within a 2.0 RMSD (root-mean-square deviation) tolerance of each other, were grouped together in clusters. The results of the docking experiments were evaluated by calculating the positional RMSD of the corresponding atoms of each conformation.

Molecular docking of 1, 2, 3 and 4 to EGFR template: To prepare 1, 2, 3 and $\mathbf{4}$ for docking with four constructed templates, all hydrogens were added and Gasteiger charges were assigned ${ }^{16}$. Auto Dock Tools was used to merge nonpolar hydrogens and define which bonds were rotatable. Compounds 1, 2, 3 and $\mathbf{4}$ were docked to the EGFR template by using a Lamarkian genetic algorithm search. Each docking trial for the ligand was initiated with a randomly generated population of 150 ligand orientations and the highest affinity orientation was selected after 2 million energy evaluations had been performed. The resulting ligand orientations from 150 trials with a $2.0 \AA$ RMSD tolerance of each other were grouped together as clusters. The final docked structure, docked energy and predicted free energy of binding were used for the analysis of its interaction with the active site.

\section{RESULTS AND DISCUSSION}

The isolation of EtOAc extract of $C$. petiolata using chromatographic methods yielded 4 labdanes, labda-8(17),12diene-15,16-dial (1) ${ }^{17}, 15,16$-bisnorlabda-8(17),11-diene-13one $(\mathbf{2})^{18}, 15$-epi-coronarin D $(\mathbf{3})^{19}$, and coronarin D methyl ether (4) ${ }^{20}$, along with stigmasterol (5) and vanillin (6) (Fig. 1). The structure of all the isolated compounds were elucidated by spectroscopic methods and by comparison with those previously reported in the literature. Compounds 1-4 were evaluated for cytotoxicity against cholangiocarcinoma cell lines, KKU-100, KKU-M139, KKU-M156, KKU-M213 and KKU-M214 as well as normal cells (Vero cells) ${ }^{13}$ and their activities are shown in Table-1. The standard drug was ellipticine. Among these cell lines, KKU-100 was the least sensitive cell line which showed the highest $\mathrm{IC}_{50}$ value of $6.21 \mathrm{mg} / \mathrm{mL}$ to ellipticine. It was found that aldehyde derivative $\mathbf{1}$ showed weak cytotoxicity

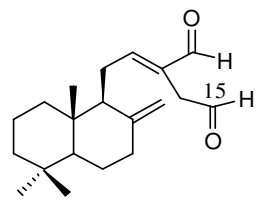

(1)

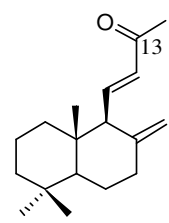

(2)

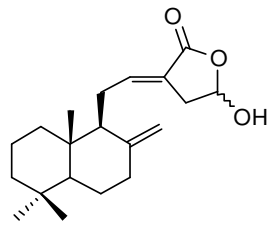

(3)

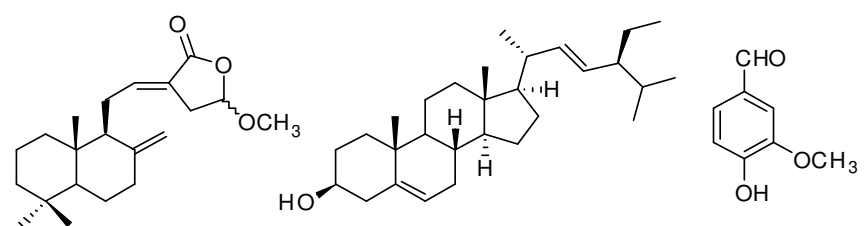

(4) (5)

(6)

Fig. 1. Chemical structure of all compounds (1-6) 
TABLE-1

CYTOTOXICITY OF ALL COMPOUNDS AGAINST CHOLANGIOCARCINOMA CELL LINES*

\begin{tabular}{crrrrrr}
\hline \multirow{2}{*}{ Compound } & \multicolumn{7}{c}{$\mathrm{IC}_{50}(\mu \mathrm{g} / \mathrm{mL})$} \\
\cline { 2 - 7 } & \multicolumn{1}{c}{ KKU-100 } & \multicolumn{1}{c}{ KKU-M139 } & \multicolumn{1}{c}{ KKU-M156 } & \multicolumn{1}{c}{ KKU-M213 } & \multicolumn{1}{c}{ KKU-M214 } & \multicolumn{1}{c}{ Vero cells } \\
\hline $\mathbf{1}$ & $35.50 \pm 0.01$ & $32.65 \pm 0.28$ & $22.43 \pm 0.65$ & $31.71 \pm 0.69$ & $30.81 \pm 0.01$ & $9.97 \pm 0.02$ \\
$\mathbf{2}$ & $14.16 \pm 0.02$ & $6.10 \pm 0.03$ & $8.79 \pm 0.05$ & $7.45 \pm 0.48$ & $6.13 \pm 0.02$ & $10.08 \pm 0.02$ \\
$\mathbf{3}$ & $7.40 \pm 0.01$ & $9.66 \pm 0.02$ & $7.46 \pm 0.26$ & $5.40 \pm 0.04$ & $11.10 \pm 0.04$ & $4.30 \pm 0.02$ \\
$\mathbf{4}$ & $15.68 \pm 0.02$ & $10.42 \pm 0.06$ & $13.47 \pm 0.12$ & $10.14 \pm 0.06$ & $8.06 \pm 0.36$ & $10.98 \pm 0.82$ \\
Ellipticine & $6.21 \pm 0.05$ & $1.11 \pm 0.07$ & $2.30 \pm 0.41$ & $0.40 \pm 0.02$ & $0.25 \pm 0.01$ & $2.29 \pm 0.05$ \\
\hline *Data shown are from triplicate experiments, NR $=$ no response at $>75 \mu \mathrm{M}$ & &
\end{tabular}

against all cell lines. Labdane $\mathbf{2}$ exhibited strong cytotoxicity against KKU-M139, KKU-M156, KKU-M213 and KKU$\mathrm{M} 214$ with $\mathrm{IC}_{50}$ values ranging from 6-8 $\mathrm{mg} / \mathrm{mL}$. Compound 4 showed moderate cytotoxicity against all cell lines with $\mathrm{IC}_{50}$ values ranging from $10-15 \mathrm{mg} / \mathrm{mL}$, except KKU-M214 cell line which showed an $\mathrm{IC}_{50}$ value of $8.06 \mathrm{mg} / \mathrm{mL}$. Interestingly, 3 exhibited strongest cytotoxicity against all cell lines especially KKU-100, KKU-M156 and KKU-M213 cell lines with $\mathrm{IC}_{50}$ values of 7.40, 7.46 and $5.4 \mathrm{mg} / \mathrm{mL}$, respectively. However, this compound also showed strong cytotoxicity against Vero cells $\left(\mathrm{IC}_{50}=4.3 \mathrm{mg} / \mathrm{mL}\right)$. It is interesting to note that 3 showed the cytotoxic activity against KKU-100 cell lines at nearly the same level as the ellipticine standard. Comparing with $\mathbf{4}$, it is suggested that the hemiacetal derivative at the $\mathrm{C}-15$ position is favorable for cholangiocarcinoma cell lines.

It has been reported that the epidermal growth factor receptor (EGFR) is found to play an important role in the cell proliferation of cholangiocarcinoma ${ }^{4,7}$. The validation result of the selective inhibitor [6,7-bis(2-methoxy-ethoxy)-quinazoline-4-yl]-(3-ethynylphenyl) amine (ligand I) with an EGFR template showed a good match for docking and a crystallographic binding orientation with RMSD of $1.67 \AA$ (Fig. (2). From the validation result, the constructed template is a good model system for predicting ligand binding orientation and binding energy. The docking results using AutoDock 4 indicate that 3 interacted with EGFR through the $2 \mathrm{H}$-bonds at Gln767 and Met769 with binding energy of $-6.89 \mathrm{kcal} / \mathrm{mol}$ (Table-2). The oxygen atom of lactone moiety forms a hydrogen bond with the H-N of Met769 (bond length $1.635 \AA$ ) and hydroxyl group of $\mathbf{3}$ forms a hydrogen bond with the oxygen of Gln767 (bond length $2.034 \AA$ ). Compound 4 also interacted with EGFR through $1 \mathrm{H}$-bond at Met769 with binding energy of -6.86 $\mathrm{kcal} / \mathrm{mol}$. As in 3, the oxygen atom in the lactone ring forms a hydrogen bond with the H-N of Met769 (bond length 1.644 $\AA$ ). These docking results confirm the stronger cytotoxic activity of $\mathbf{3}$ than $\mathbf{4}$. In addition, $\mathbf{1}$ and $\mathbf{2}$ interacted with EGFR through the $1 \mathrm{H}$-bond at Lys721 with binding energy of -7.04 and $-6.86 \mathrm{kcal} / \mathrm{mol}$, respectively. The docking results show that the hydrogen at the ammonium group of Lys721 forms

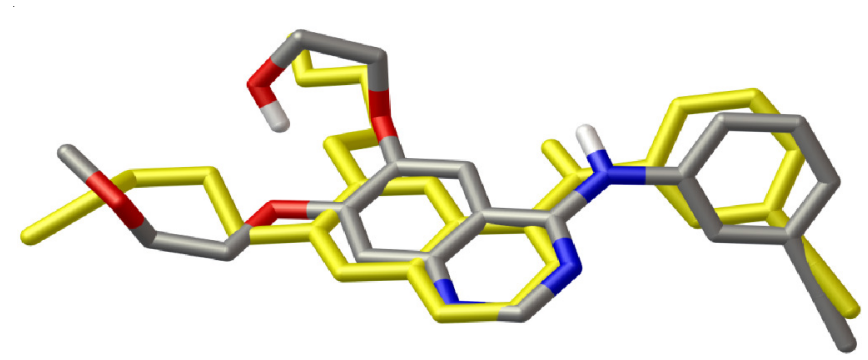

Fig. 2. Superposition of crystallographic (green stick model) and docked orientation: ligand I (atom color) bound to EGFR template
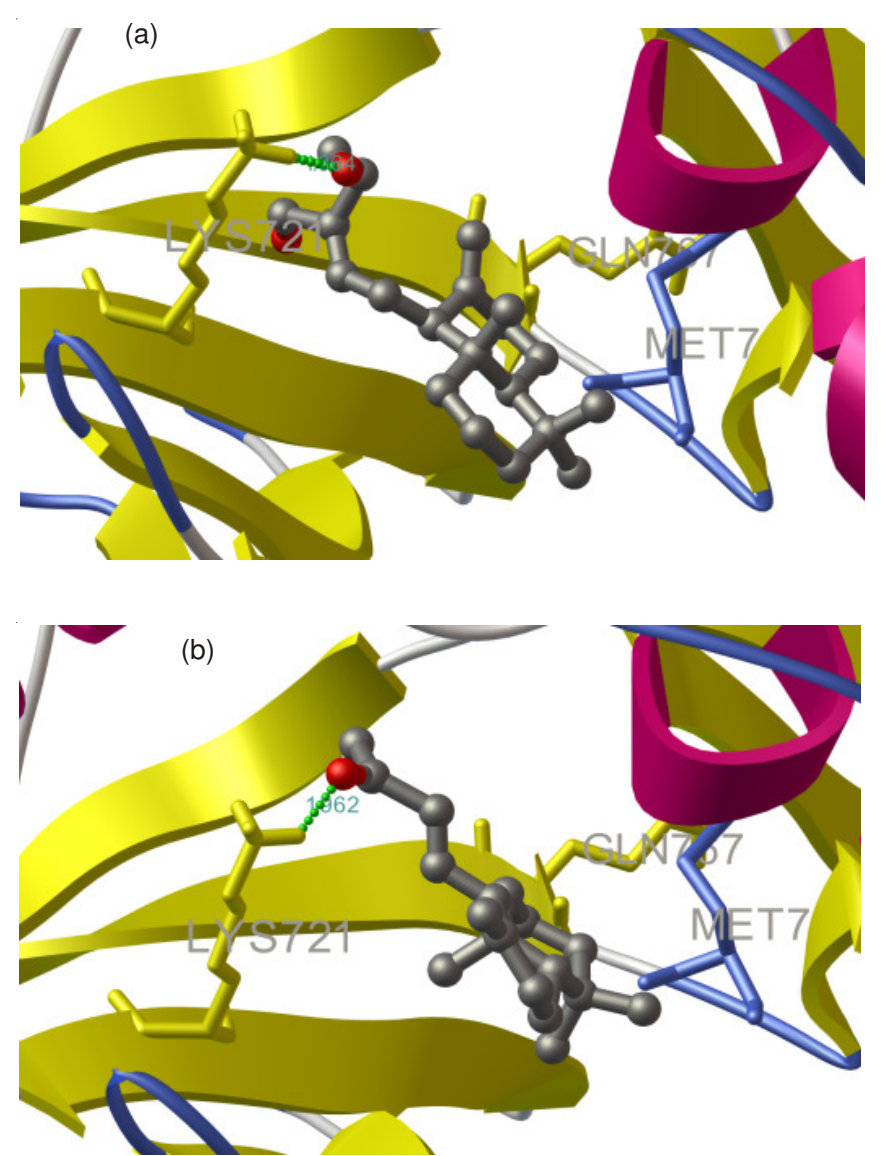

TABLE-2

DOCKING OF FOUR COMPOUNDS (1-4) ON EGFR KINASE

\begin{tabular}{|c|c|c|c|c|c|}
\hline \multirow[b]{2}{*}{ Compound } & \multirow{2}{*}{$\begin{array}{c}\text { Number of } \\
\text { H-bond }\end{array}$} & \multicolumn{3}{|c|}{ Geometric filters } & \multirow{2}{*}{$\begin{array}{c}\mathrm{E}_{\text {binding }} \\
\text { (kcal/mol }\end{array}$} \\
\hline & & Amino acid residue & H-bonding atom & $\begin{array}{l}\text { Distance } \\
(\AA)\end{array}$ & \\
\hline 1 & 1 & Lys721 & $\mathrm{O}(\mathrm{C}=\mathrm{O})$ & 1.983 & -7.04 \\
\hline 2 & 1 & Lys721 & $\mathrm{O}(\mathrm{C}=\mathrm{O})$ & 1.962 & -6.86 \\
\hline 3 & 2 & Gln767 Met769 & $\mathrm{H}(\mathrm{O}-\mathrm{H}) \mathrm{O}$ (lactone) & 2.0341 .635 & -6.89 \\
\hline 4 & 1 & Met769 & O (lactone) & 1.644 & -6.86 \\
\hline
\end{tabular}



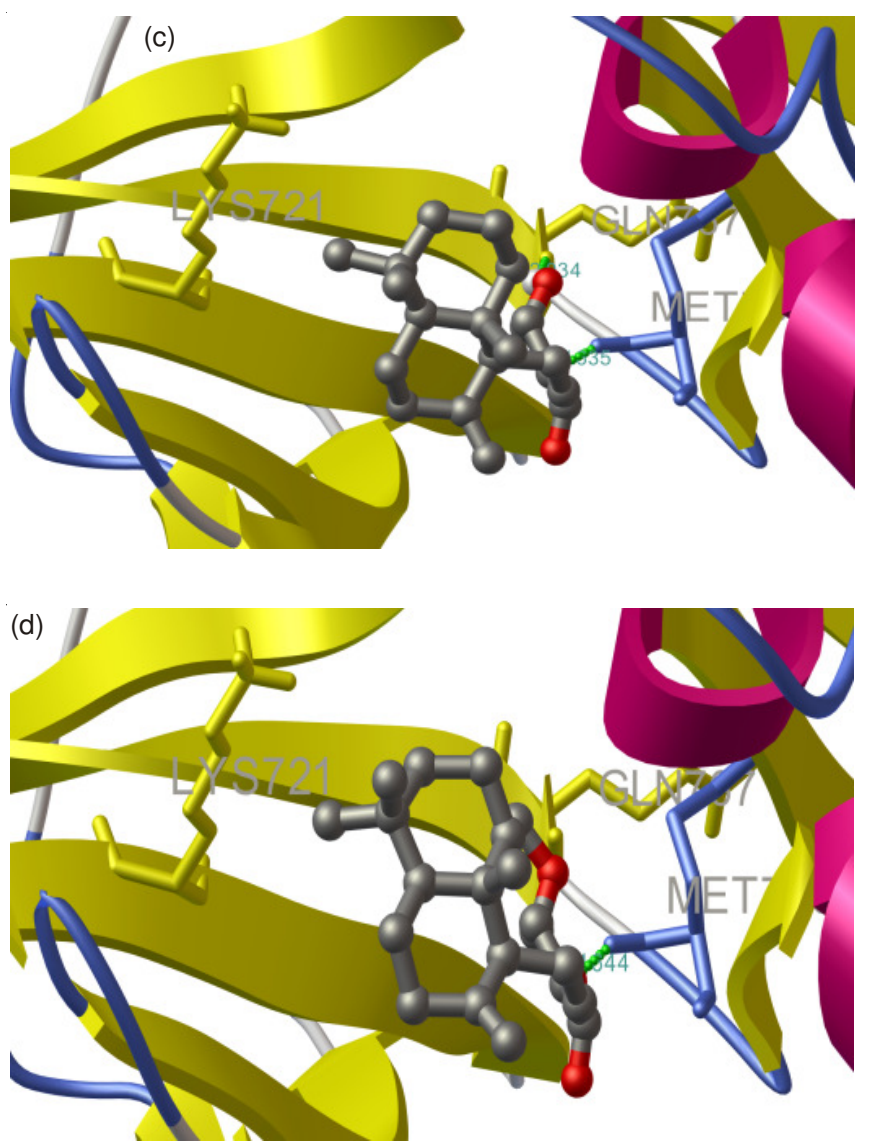

Fig. 3. Docked conformation of (a) compound 1, (b) compound 2, (c) compound $\mathbf{3}$, and (d) compound $\mathbf{4}$ on EGFR kinase. Hydrogen bonds are represented with dashed green lines

a hydrogen bond with aldehydic oxygen (C-15) in $\mathbf{1}$ and with ketone oxygen (C-13) in $\mathbf{2}$ (Fig. 3). In this study, the computational analysis confirmed the highest cytotoxicity results of compound 3.

\section{ACKNOWLEDGEMENTS}

The authors thank the Center of Excellence for Innovation in Chemistry (PERCH-CIC) and the Science Achievement Scholarship of Thailand (SAST), Office of the Higher Education
Commission, Ministry of Education and the National Research University Project of Thailand through the Advanced Functional Materials Cluster of Khon Kaen University for financial support.

\section{REFERENCES}

1. B. Sripa and C. Pairojkul, Curr. Opin. Gastroenterol., 24, 349 (2008).

2. L.K. Sampson, S.M. Vickers, W. Ying and J.O. Phillips, Cancer Res., 57, 1743 (1997).

3. W. Loilome, P. Yongvanit, C. Wongkham, N. Tepsiri, B. Sripa, P. Sithithaworn, S. Hanai and M. Miwa, Mol. Carcinog., 45, 279 (2006).

4. U. Songsiang, S. Pitchuanchom, C. Boonyarat, C. Hahnvajanawong and C. Yenjai, Eur. J. Med. Chem., 45, 3794 (2010).

5. U. Songsiang, T. Thongthoom, P. Zeekpudsa, V. Kukongviriyapan, C. Boonyarat, J. Wangboonskul and C. Yenjai, Sci. Asia, 38, 75 (2012).

6. S. Pitchuanchom, C. Boonyarat, S. Forli, J.A. Olson and C. Yenjai, Comput. Biol. Med., 42, 106 (2012).

7. D. Yoshikawa, H. Ojima, M. Iwasaki, N. Hiraoka, T. Kosuge, S. Kasai, S. Hirohashi and T. Shibata, Br. J. Cancer, 98, 418 (2008).

8. J. Stamos, M.X. Sliwkowdki and C. Eigenbrot, J. Biol. Chem., 277, 46265 (2002).

9. X. Lin, S. Ji, R. Li, Y. Dong, X. Qiao, H. Hu, W. Yang, D. Guo, P. Tu and M. Ye, J. Nat. Prod., 75, 2121 (2012).

10. G.N. Roth, A. Chandra and M.G. Nair, J. Nat. Prod., 61, 542 (1998).

11. N. Chimnoi, C. Sarasuk, N. Khunnawutmanotham, P. Intachote, S. Seangsai, B. Saimanee, S. Pisutjaroenpong, C. Mahidol and S. Techasakul, Phytochem. Lett., 2, 184 (2009).

12. L.G. Mahaira, C. Tsimplouli, N. Sakellaridis, K. Alevizopoulos, C. Demetzos, Z. Han, P. Pantazis and K. Dimas, Eur. J. Pharmacol., 666, 173 (2011).

13. P. Skehan, R. Storeng, D. Scudiero, A. Monks, J. McMahon, D. Vistica, J.T. Warren, H. Bokesch, S. Kenney and M.R. Boyd, J. Natl. Cancer Inst., 82, 1107 (1990).

14. S.J. Weiner, P.A. Kollman, D.A. Case, U.C. Singh, C. Ghio, G. Alagona, S. Profeta and P. Weiner, J. Am. Chem. Soc., 106, 765 (1984).

15. (a) G.M. Morris, D.S. Goodsell, R. Huey and A.J. Olson, J. Comput. Aided Mol. Des., 10, 293 (1996).; (b) G.M. Morris, D.S. Goodsell, R.S. Halliday, R. Huey, W.E. Hart, R.K. Belew and A.J. Olson, J. Comput. Chem., 19, 1639 (1998).

16. J. Gasteiger and M. Marsili, Tetrahedron, 36, 3219 (1980).

17. P.S. Hema and M.S. Nair, Biochem. Syst. Ecol., 37, 52 (2009).

18. H. Itokawa, M. Morita and S. Mihashi, Chem. Pharm. Bull. (Tokyo), 28, 3452 (1980).

19. D.B. Alan Sheeja and M.S. Nair, Biochem. Syst. Ecol., 44, 264 (2012).

20. P.V. Kiem, N.T.K. Thuy, H.L.T. Anh, N.X. Nhiem, C.V. Minh, P.H. Yen, N.K. Ban, D.T. Hang, B.H. Tai, N.V. Tuyen, V.B. Mathema, Y.S. Koh and Y.H. Kim, Bioorg. Med. Chem. Lett., 21, 7460 (2011). 